\title{
What is anthropological about The Perfect Human?
}

\section{ABSTRACT}

Jørgen Leth has classified The Perfect Human as an anthropological film. But is the film anthropological at all? This article explores Leth's connections with anthropology and finds that he is more inspired by anthropological framing than he is by anthropological research methods.

Jørgen Leth was working as a journalist in his early twenties when he first became interested in anthropology. For a short period, he studied anthropology at the University of Copenhagen. When asked, he describes his initial interest in anthropology as methodological:

I was romantically drawn by the notion of categorizing and describing things. I was fascinated by foreign cultures, I have always been a traveler, someone who went out and looked at the exotic reality from other parts of the world. I was interested in finding some methodological tools.

(Leth in Overgaard 2004, my translation)

When looking at Leth's The Perfect Human, it is not anthropology's methodological tools of gathering information but rather a specific anthropologist's way of presenting anthropology that appears to be Leth's main inspiration. The anthropological presentations that have inspired Leth are not those

\section{KEYWORDS}

anthropology ethnography fieldwork genre framing 
favoured by current schools of anthropology, but those of an anthropologist who worked almost 100 years ago, Bronislaw Malinowski.

\section{LETH AND MALINOWSKI}

The British anthropologist Malinowski went on expeditions to the Trobriand Islands in 1915-1916 and in 1917-1918, in order to study the everyday life of the islanders. Upon returning, Malinowski published three books, each focusing on different aspects of the Trobriand way of living. Jørgen Leth read Malinowski's second book on the Trobriand Islanders, The Sexual Life of Savages in North-Western Melanesia (1929), and was inspired by its ways of presenting another culture.

Signifying a time when anthropologists came from the West and the people studied were from an exotic other world, Malinowski's narrative distances itself very much from the people studied, describing the 'savages' as an exotic other species. Comparing the writing style in Malinowski's The Sexual Life of Savages in North-Western Melanesia (1929) to the words of the narrator in The Perfect Human, the narrative voice appears very similar. This similarity is no coincidence, indeed Leth has confirmed that he uses Malinowski's ways of describing others as a model for his own work:

The way he [Malinowski] describes the locals has simply always been a model for me. [...] It is not really his philosophical qualities, but more his ways of presenting, that distanced way of storytelling. It is his way of viewing which I find useful.

(Leth in Leifer 1999: 144, my translation)

Consider how the narrator describes the film's project (Shots 6-8). Then, read the first sentences in the first chapter of The Sexual Life of Savages in NorthWestern Melanesia: 'Man and Woman in the Trobriand Islands - their relations in love, in marriage, and in tribal life - this will be the subject of the present study' (Malinowski 1929: 1). When comparing the words and tone of voice of the narrator in The Perfect Human to that of Malinowski's writings, the inspiration is clear. In fact, one could argue that the narrator in The Perfect Human talks and presents details just as Malinowski does throughout his 1929 book.

\section{AN ANTHROPOLOGICAL SET-UP?}

Does the fact that the words of the narrator resemble the narrative of Malinowski (1929) make The Perfect Human anthropological? It was crucial to Malinowski's work that he had spent years living among the people he studied. This long-stay approach enabled a new insight into the culture studied. While Malinowski was not the founder of anthropological fieldwork, he was one of its founding fathers, putting focus on the importance of long-stay fieldwork. This anthropological method is not one which Leth adheres to.

Today, Malinowski is still a key figure presented to first year anthropology students. His methods of fieldwork are still important to the discipline of anthropology, though his distancing ways of presenting fieldwork are no longer favoured. Much inspired by his works, anthropology today concerns itself with studying people through researching topics such as the everyday life, rituals, habits and values of a selected group of people. Despite differences 
in focus, anthropology as a discipline is united in the belief that the study of humans is closely linked to a study of the environment that these humans exist in. Anthropologists thus aim to produce a situated knowledge showing how the people studied exist in their natural environment. Considering the importance of fieldwork then, for an anthropologist to place two selected people (actors) from a group in a closed room, give them props and explain to them how they should behave would run counter to the very principles of anthropology.

Even if the actors improvise their performance, as has been said of the actors in The Perfect Human, the setting and frame of these actions have already been created by Leth as the film's director. By putting two selected people in a room (Shots 31 and 37), and giving them props with which to interact, the researcher's lens is affecting any behaviour these two people may have - and any social behaviour they may have in their natural environment is lost. The only two people appearing in the film are not interacting much with each other. When they do interact they seem to be acting in very stylized slowmotion poses, very much aware of the camera (Shot 50). Thus, in this film, the two people are disconnected from any other social or cultural environment. In fact, rather than being connected to a social or cultural world, they appear isolated and boxed away from time and place in the white room. In this sense then, the film's set-up is not anthropological.

\section{NOT ETHNOGRAPHY, BUT SOCIAL COMMENTARY}

One of anthropology's much-used definitions of culture derives from a metaphor Clifford Geertz borrowed from Max Weber, namely that

man is an animal suspended in webs of significance he himself has spun [...] I take culture to be those webs, and the analysis of it to be therefore not an experimental science in search of a law but an interpretive one in search of meaning.

For Geertz, culture is not something locked inside people's heads but rather visible in actions and in symbols through which members of a society communicate crucial ideals, world-views and value orientations. Inspired by anthropology, Leth may have thought of the film as a way of highlighting some of the actions and symbols used by an elite group of people at the time - the pipe, the extravagant dinner, the fine clothes and the make-up used. And above all, the film appears to be a hint at an obsession with looks and style of the time. From this perspective, Leth appears inspired by anthropology as a way of labelling and categorizing phenomena of the world. But the apparent lack of long-stay research and the lack of natural interaction with other humans in the film makes The Perfect Human untrustworthy as ethnography.

Just as Malimowski has been criticized for making the Trobriand Islander appear like an exotic other, so the two perfect humans in the film appear to be enjoying an unobtainable status. The viewer is invited to 'look', 'observe' and study the humans, as if they or their behaviour were for sale. The narrator appears keen to do a type of fictive investigation, cataloguing the perfect human with an observing distance. However, this investigation turns into a cataloguing of looks and all that is superficial about this special type of 
human which the narrator describes as perfect. In this way, the film suggests that the people portrayed are more interested in superficial issues, looks and appearances. As a social commentary then, the film works well.

\section{THE IRONIC STANCE}

It would seem that Leth has cast the narrator in the role of anthropologist. The viewer is made aware from the start (Shot 3) that the narrator is labelling, categorizing and describing the actions of the people on-screen, and that this narrator is defining the two characters as perfect. On top of such actions as the man moving (Shot 22), the woman walking (Shot 24), the man falling (Shot 30) or the man dancing (Shot 37), the stern-sounding narrator describes the scenes. 'The perfect human is moving in a room', says the narrator (Shot 22). This way of presenting themes and concepts is very much in the vein of Malinowski's writing style. Titling the film Anthropological hints at an overarching aim towards the fieldwork-based, truth-portraying stance. But to an anthropologist, the very idea that it should be possible to study how the perfect human functions simply by seeing two humans alone in a white room might seem almost absurd.

All anthropologists are faced with the question as to whether they manage to portray a culture truthfully and objectively. With The Perfect Human Leth does not appear to be worrying about objectivity or truth. However, the narrator speaks in the tone of an anthropologist. In this way, the film manages to use anthropological presentation methods to make an observation about anthropology. Rather than being an anthropological film about perfect humans then, the film offers an ironic stance to the discipline of anthropology, which makes the viewer ponder: is it even possible to describe humans truthfully? And who is to determine what is perfect?

\section{REFERENCES}

Geertz, C. (1973), The interpretation of Cultures, New York: Basic Books.

Leifer, A. (1999), Også $i$ dag oplevede jeg noget... Samtaler med Jørgen Leth, Copenhagen: Informations Forlag.

Malinowski, B. (1929), The Sexual Life of Savages in North Western Melanesia: An Ethnographic Account of Courtship, Marriage Life and Family among the Natives of the Trobriand Islands, British New Guinea, New York: Eugenics Publishing Company.

Overgaard Nielsen, L. (2004), 'Jørgen Leth: En filmsproglig æstetiker og

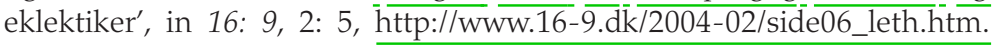
Accessed 28 October 2014.

\section{SUGGESTED CITATION}

Thomsen, L. H. (2015), 'What is anthropological about The Perfect Human?', Short Film Studies 5: 2, pp. 161-165, doi: 10.1386/sfs.5.2.161_1

\section{CONTRIBUTOR DETAILS}

Line Hassall Thomsen finished her Ph.D. study of TV news journalists at Aarhus University in 2013. The study was based on anthropological methods of participant observation among journalists at DR and TV2 (in Denmark) and the BBC and ITV (in England). Before this, Line spent over ten years working 
as a journalist herself, in England, Denmark and internationally. Today she researches, teaches and also still works in journalism.

E-mail: lht@dac.au.dk

Line Hassall Thomsen has asserted her right under the Copyright, Designs and Patents Act, 1988, to be identified as the author of this work in the format that was submitted to Intellect Ltd. 


\section{Mosaic, a journal for the interdisciplinary study of literature}

\section{Forthcoming Publications}

QUEER/AFFECT 48.1 (Mar. 2015) This issue examines the potential of queer intervention into affect theory, exploring non-normative ways of feeling, existing, and relating. Essay topics include emotion and expression, trauma theory, collectivity, shame, desire, queer subjectivity, and performativity, among others.

\section{A MATTER OF LIFEDEATH CONFERENCE PROCEEDINGS I-III} 48.2-4 (June, Sep., Dec. 2015) Together these three issues will feature keynote lectures given by Andrea Carlino, Françoise Dastur, and Elisabeth Weber, along with selected papers presented by participants during Mosaic's "A matter of lifedeath" conference. The essays reflect the conference's engagement with questions of life and death in ways that avoid reductive gestures and exceed oppositions between animate and inanimate, human and animal, presence and absence, the humanities and the sciences, the living and the dead.

\section{Recent Publications}

FEATURING: MICHAEL NAAS 47.4 (Dec. 2014) This issue features a "Crossings" interview with Michael Naas, Professor of Philosophy at DePaul University. The issue also includes two essays by Professor Naas on the work of Hélène Cixous.

ROMANCE 47.2 (June 2014) This Mosaic special issue engages the rich history of the word "Romance," with essays on "the romantic," the roman, romantic fiction, Romanticism, "the Romantics," and the state of the love story in literature and film. 